\title{
Interaction of Campylobacter pyloridis with human immune defence mechanisms
}

\author{
H. PRUUL, P. C. LEEt, C. S. GOODWIN* and P. J. MCDONALD
}

Department of Clinical Microbiology, Flinders Medical Centre, Bedford Park 5042, South Australia and - Department of Microbiology, Royal Perth Hospital, Perth 6000, Western Australia

\begin{abstract}
Summary. The in-vitro susceptibility to host immune defence mechanisms of Campylobacter pyloridis was investigated. C. pyloridis was sensitive to antibodydependent complement-mediated bactericidal activity of serum. The bacteria were phagocytosed and efficiently killed by polymorphonuclear neutrophils in the presence of serum opsonins. Serum opsonin depletion studies indicated that an intact classical complement pathway was required for optimal phagocytic killing.
\end{abstract}

\section{Introduction}

Campylobacter pyloridis is a newly described gram-negative bacterium (Warren, 1983; International Journal of Systematic Bacteriology, 1985; Marshall et al., 1985a). It is frequently isolated from the antral mucosa of adults and children presenting with gastritis (Jones et al., 1984; Langenberg et al., 1984; Rollason et al., 1984; Hill et al., 1986), and has been observed associated with histologically demonstrable inflammation with neutrophil infiltration (Marshall and Warren, 1984; Phillips et al., 1984; Shousha et al., 1984; Marshall et al., 1985b). Gastritis associated with these bacteria is often accompanied by an elevated antibody titre to $C$. pyloridis (Eldridge et al., 1984; Jones et al., 1984). While the involvement of $C$. pyloridis in the pathogenesis of gastritis is not clearly understood, its close association with an inflammatory response suggests a pathological role. In this study, we investigated the interaction of $C$.pyloridis with host defence factors to determine the ability of serum factors and polymorphonuclear neutrophils (PMN) to eliminate this potential pathogen.

\section{Material and methods}

\section{Bacteria}

The $C$. pyloridis isolate used was from a patient with a 4-week history of dyspepsia. Endoscopy revealed duodenal ulceration and histology of biopsy specimens taken from the edge of the ulcer showed PMN infiltration and spiral bacteria, often associated with PMN. This tissue

Received 5 Jun. 1986; accepted 3 Jul. 1986.

† Correspondence should be sent to Dr P. C. Lee. was minced in normal saline and cultured at $37^{\circ} \mathrm{C}$ in microaerophilic conditions, provided by CampyPak $\mathrm{H}_{2-}-$ $\mathrm{CO}_{2}$ generator envelopes (BBL Microbiology Systems, Cockeysville, MD, USA) in GasPak jars (BBL) with no catalyst. A selective medium consisting of Brucella Base Agar supplemented with defibrinated sheep blood $10 \%$, Vitox $2 \%$ and Skirrow's ingredients (Oxoid), was used for initial isolation. Subsequently the organisms were grown on chocolate agar. The isolate was identified by criteria described by Marshall et al. (1985a).

The inoculum for bactericidal assays was prepared from bacteria grown for 3 days on chocolate agar and scraped into Hanks's Balanced Salts Solution with gelatin $0.1 \%$ (G-HBSS). The bacteria were washed and resuspended in G-HBSS to yield $(2-5) \times 10^{7} \mathrm{cfu} / \mathrm{ml}$.

\section{Bactericidal assays}

The bactericidal activity of serum was determined in tubes containing $2 \times 10^{6}$ bacteria and various concentrations of normal human serum in the absence or presence of immune serum $1 \%$ in G-HBSS, $p \mathrm{H} 7 \cdot 0$. Phagocytic killing was investigated in reaction mixtures consisting of $2 \times 10^{6} \mathrm{PMN}$ and $2 \times 10^{6}$ bacteria in the presence of normal serum $5 \%$ and immune serum $1 \%$; The total reaction volume was $0.4 \mathrm{ml}$. The assay tubes were flushed with a mixture of $\mathrm{CO}_{2} 5 \%$ in nitrogen and incubated at $37^{\circ} \mathrm{C}$ with reciprocating agitation at 110 oscillations/min. At appropriate times, $20-\mu \mathrm{l}$ portions were added to sterile distilled water to dilute the bacteria and disrupt the PMN. After exposure to water for 10-20 min with frequent vigorous agitation, portions were spread on the surface of chocolate-agar plates; these were incubated at $37^{\circ} \mathrm{C}$ for 4 days in microaerophilic conditions and the colonies were then counted.

\section{Neutrophils and sera}

PMN were separated from heparinised peripheral 
blood of normal human volunteers by dextran sedimentation and differential centrifugation in Ficoll-Hypaque. Erythrocytes were removed by hypotonic lysis. PMN were suspended in G-HBSS to a density of $1 \times 10^{7}$ viable $\mathrm{PMN} / \mathrm{ml}$. Viability was determined by trypan blue exclusion; the preparations used contained $>95 \%$ viable PMN. Normal human serum from the peripheral blood of six individuals was pooled. Serum devoid of complement activity was produced by heating it at $56^{\circ} \mathrm{C}$ for $30 \mathrm{~min}$. Serum deficient in alternate complement pathway activity was prepared by heating at $50^{\circ} \mathrm{C}$ for $30 \mathrm{~min}$, as described by Götze and Müller-Eberhard (1971). Calcium-dependent $\mathrm{C} 142$ activity of complement was blocked by treatment with $10 \mathrm{mM}$ ethyleneglycol bisamino tetra-acetate (EGTA; Sigma Chemical Co., St Louis, MI, USA) in the presence of an equimolar concentration of $\mathrm{MgCl}_{2}$ (Fine et al., 1972). Residual C3 activity of depleted sera was determined by the antibodyindependent alternate-pathway lysis of rabbit red cells, as described by Platts-Mills and Ishizaka (1974). The immune serum was that obtained from the patient on the day of biopsy. Tests for antibody to $C$. pyloridis were performed by an enzyme-linked immunosorbent assay (ELISA) with an acid-glycine extract of $C$. pyloridis as the antigen. The method was that of Blaser and Duncan (1984) with additional controls; a positive serum was titrated on each plate to provide a standard curve. In a study of biopsy-positive and biopsy-negative patients, it was determined that a result $>200$ ELISA units was highly associated with the presence of $C$. pyloridis in the gastric mucosa (Goodwin, Blincow and Peterson, unpublished data). The homologous immune serum antibody titre was 4525 ELISA units. The range of titres of individual sera contributing to the pool of normal human serum was $65-200$ units. Sera were stored at $-20^{\circ} \mathrm{C}$ for up to 2 months and thawed once only. No aggregation of bacteria by these sera was observed by microscopy.

Serum free of antibody to $C$. pyloridis was obtained by absorption of normal human serum three times at $0^{\circ} \mathrm{C}$ with $c .10^{10}$ washed, packed $C$. pyloridis cells scraped from a chocolate-agar plate on which the bacteria had been grown for 3 days. The absorbed serum was filtered through a cellulose acetate membrane and used immediately.

\section{Results}

Normal human serum was bactericidal for $C$. pyloridis at concentrations $>5 \%$ (fig. 1A). The total number of bacteria killed during the period of the experiment and the rate of killing both increased as the concentration of serum was raised. Serum heated at $56^{\circ} \mathrm{C}$ to remove complement had no activity against $C$. pyloridis. Serum treated with EGTA to remove calcium ions, and serum heated at $50^{\circ} \mathrm{C}$ to inactivate factor $\mathrm{B}$ failed at a concentration of $20 \%$ to kill bacteria. The effect of immune serum $1 \%$ upon killing of $C$. pyloridis in normal serum is shown in fig. $1 \mathrm{~B}$. The rate and extent of killing by normal human serum was increased in the presence of immune serum: while serum $2 \cdot 5 \%$ failed to kill significant numbers of bacteria when used alone (fig. 1A), c. $80 \%$ of the bacteria were

Table. Effect of antibody and complement depletion on bactericidal and opsonic activity of serum against $C$. pyloridis

$\log _{10}$ fall* in viable count after incubation for $30 \mathrm{~min}$ in the presence of

\begin{tabular}{|c|c|c|}
\hline \multirow[b]{2}{*}{ Serum preparation } & \\
\hline & $5 \times 10^{6} \mathrm{PMN} / \mathrm{ml}$ & No PMN \\
\hline Normal human serum $5 \%$ & $1 \cdot 06 \pm 0 \cdot 17$ & $0 \cdot 18 \pm 0 \cdot 13$ \\
\hline Serum $(5 \%)$ absorbed with $C$. pyloridis & $0.4 \pm 0.1(\mathrm{p}<0.05)$ & $0 \cdot 11 \pm 0 \cdot 14$ (n.s.) \\
\hline Immune serum $1 \%$ & $0.25 \pm 0.12(\mathrm{p}<0.05)$ & $0.12 \pm 0.08$ (n.s.) \\
\hline Absorbed serum $5 \%+$ immune serum $1 \%$ & $1 \cdot 17 \pm 0.18$ (n.s.) & $0.32 \pm 0.15$ (n.s.) \\
\hline Normal serum treated with EGTA-Mg ${ }^{++*} \dagger$ & $0.41 \pm 0.24(\mathrm{p}<0.05)$ & $0 \cdot 14 \pm 0.9$ (n.s.) \\
\hline Normal serum heated at $50^{\circ} \mathrm{C}$ for $30 \mathrm{~min} \ddagger$ & $0.5 \pm 0.18(\mathrm{p}<0.05)$ & $0.12 \pm 0.15$ (n.s.) \\
\hline Normal serum heated at $56^{\circ} \mathrm{C}$ for $30 \mathrm{~min}$ & $0.25 \pm 0.14(\mathrm{p}<0.05)$ & $0.03 \pm 0.05(\mathrm{p}<0.05)$ \\
\hline
\end{tabular}

* Mean \pm SD of at least three determinations; significance was determined with respect to the results obtained with normal $5 \%$ human serum by Student's $t$ test; n.s. $=$ not significant.

$\dagger$ EGTA $\mathrm{Mg}^{++}$-treated serum retained $84 \%$ alternate-pathway lytic activity against rabbit red cells.

$\ddagger$ The serum contained $<12 \%$ C3-lytic activity. 


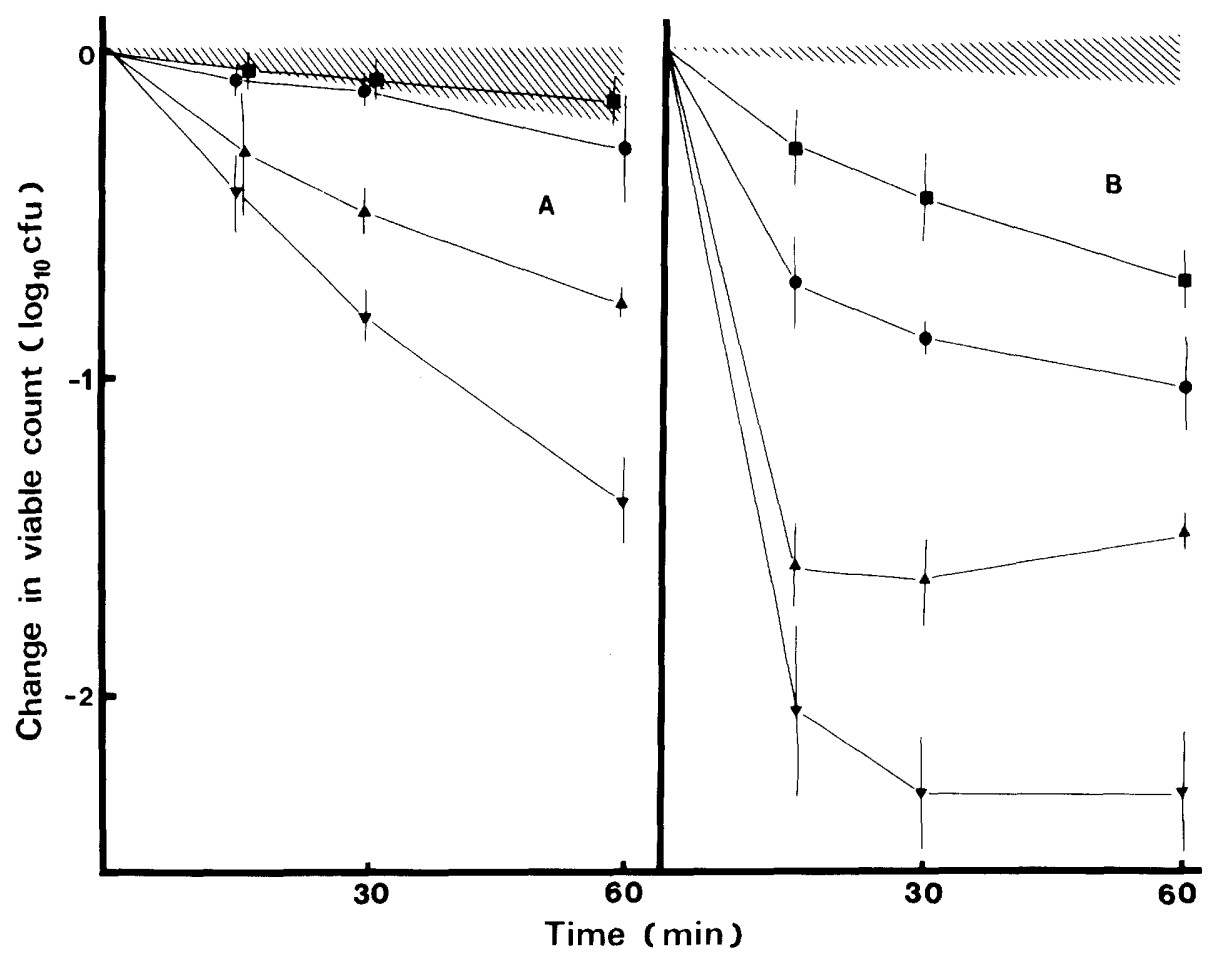

Fig. 1. Serum bactericidal activity against $C$. pyloridis incubated with various concentrations of normal human serum, (A) in the absence or (B) in the presence of immune serum $1 \%$. Normal human serum was used at concentrations of $2.5 \%(\square), 5 \%(-\square), 10 \%(-\square)$, and $20 \%(\nabla-\nabla)$. The hatched areas indicate the changes in viable counts in the presence of (A): EGTA-treated serum $20 \%$; serum heated at $50^{\circ} \mathrm{C}$ for $30 \mathrm{~min}, 20 \%$; and no added serum; (B): immune serum alone, $1 \%$; and normal serum heated for $30 \mathrm{~min}$ at $56^{\circ} \mathrm{C}, 20 \%$, in the presence and absence of immune serum $1 \%$. Each point is the mean $\pm \mathrm{SD}$ of four experiments.

killed in the presence of immune serum $1 \%$; killing at serum concentrations between $2.5 \%$ and $20 \%$ was significantly enhanced in the presence of immune serum ( $\mathrm{p}<0 \cdot 05$, Student's $t$ test). Immune serum failed to reduce the number of viable bacteria in the presence or absence of $20 \%$ normal serum that had been heated to remove complement activity.

To determine the effect of serum components on phagocytic killing, PMN were incubated with $C$. pyloridis in the presence of serum $5 \%$, immune serum $1 \%$, and the combination of normal serum and immune serum. The results are shown in fig. 2 . About $99 \%$ of the bacterial inoculum was killed in $30 \mathrm{~min}$ by PMN in the presence of normal serum $5 \%$ and immune serum $1 \%$. In the absence of immune serum, $90 \%$ of the inoculum was killed, significantly less than with the complete system ( $p<0.02$ ). Immune serum alone failed to support significant phagocytic killing. In the absence of PMN the individual serum components failed to kill the bacteria, but normal human serum and immune serum in combination were bactericidal.

To define more clearly the serum components required for phagocytic killing, various treatments were used to remove antibody and complement activity. The results are shown in the table. Classical complement pathway activity was inhibited by repeated absorption of the serum at $0^{\circ} \mathrm{C}$ with the homologous bacterial strain to remove antibody. This significantly reduced $\mathrm{PMN}$-associated killing by $\log _{10} 0.66$ ( $\left.p<0.05\right)$. Immune serum failed to support killing of bacteria by PMN in the absence of normal serum. However, the phagocytic killing mediated by the absorbed serum could be wholly restored by the addition of immune serum $1 \%$. This was not associated with significantly increased bactericidal activity in the absence of PMN. Blocking of the classical complement pathway by chelation of calcium ions with EGTA also reduced phagocytic killing.

The alternate complement pathway was inhib- 


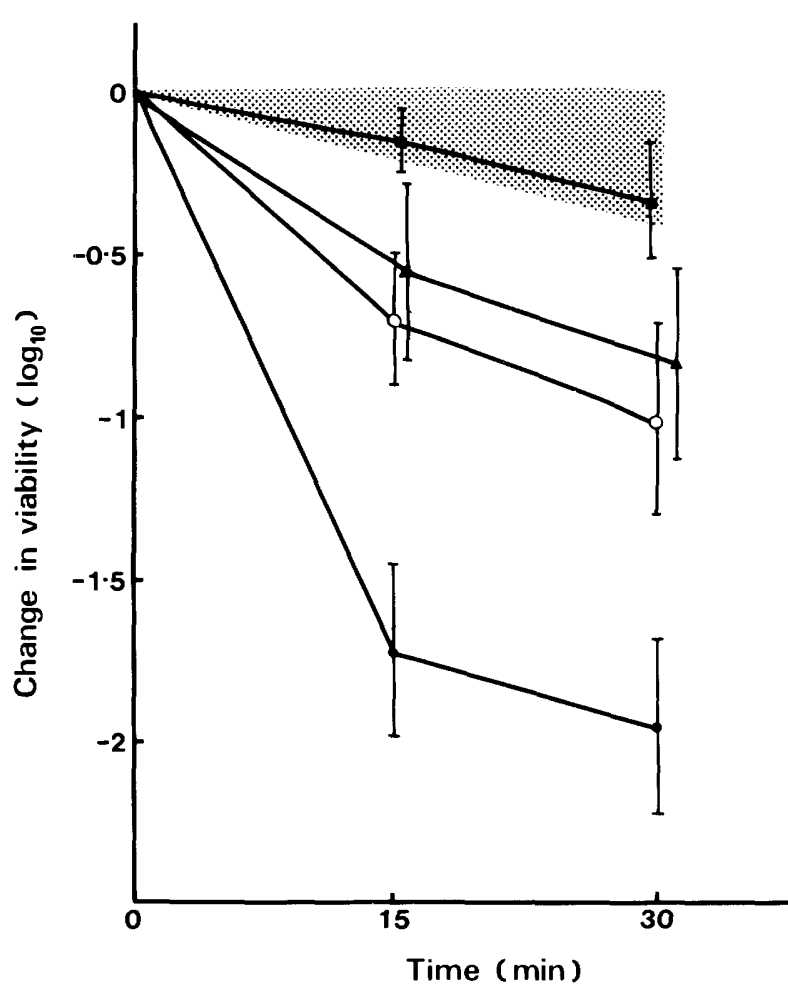

Fig. 2. Phagocytic killing of $C$. pyloridis incubated with human peripheral blood PMN in the presence of: normal human serum $5 \%(\mathrm{O}-\mathrm{O})$; immune serum $1 \%($

$\square)$; serum $5 \%$ and immune serum $1 \%(-)$. In the absence of PMN, the bacteria were incubated in the presence of normal serum $5 \%$ and immune serum $1 \%(\mathbf{A}-\mathbf{\Delta})$; immune serum, $1 \%$, alone, or serum, $5 \%$, alone (stippled area). Each point is the mean $\pm S D$ of at least four experiments.

ited by heat treatment of normal human serum at $50^{\circ} \mathrm{C}$ for $30 \mathrm{~min}$. This treatment inactivates factor $\mathrm{B}$, which is essential for the activation of $\mathrm{C} 3$ via the alternate complement pathway (Götze and Müller-Eberhard, 1971). This significantly reduced PMN-associated killing by $\log _{10} 0.56$ $(p<0.05)$. The inactivation of complement activity by heat treatment at $56^{\circ} \mathrm{C}$ abolished phagocytic killing.

In the absence of PMN, the degree of killing of $C$. pyloridis by these sera was much reduced. Untreated serum decreased the number of viable bacteria by $\log _{10} 0 \cdot 18$. The various depleted sera exhibited reduced bactericidal activity but the fall in viable count was not statistically significant except with serum depleted of complement activity by heating at $56^{\circ} \mathrm{C}$. The addition of immune serum $1 \%$ to restore antibody activity to serum absorbed with $C$. pyloridis caused an increase in bactericidal activity, but the increase was not statistically significant.

\section{Discussion}

Serum from normal human subjects is bactericidal for a wide range of gram-negative organisms through activation of components of the classical or alternate complement pathways. Smooth strains of Enterobacteriaceae are relatively resistant to serum whereas rough strains are more susceptible to the lethal action of complement and this may be associated with virulence (Rowley, 1954). Furthermore, gram-negative bacteria isolated from infected tissue, including blood, are often resistant to serum bactericidal activity (Fierer et al., 1972). However, a correlation between serum resistance and virulence has not been established for many known pathogens and gram-negative organisms that are easily killed by serum in vitro may cause severe infections in patients with defects of phagocytic killing by leucocytes (Johnston and Baehner, 1971).

In this study, a clinical isolate of $C$. pyloridis was shown to be susceptible to the bactericidal activity of high concentrations of normal serum. A requirement for activation of the classical complement pathway was demonstrated by the failure of EGTAtreated serum to kill bacteria, and serum in which alternate pathway activity was abolished by heat treatment at $50^{\circ} \mathrm{C}$ also lacked bactericidal activity. The failure of the alternate pathway of complement activation to kill serum-sensitive gram-negative bacteria has been shown previously (Götze and Müller-Eberhard, 1971). While products of the alternate pathway appear to make a significant contribution to the bactericidal activity of serum, these components are impotent per se. It is probable that an initial breach of the bacterial cell wall by components activated by the classical pathway is required before they can exert their lethal effect.

The ability of immune serum to enhance the bactericidal activity of normal human serum indicates clearly the dependance of the intact complement sequence for optimal killing of $C$. pyloridis in the serum bactericidal system.

Rapid killing of opsonised bacteria by PMN has previously been described for extracellular bacteria other than C. pyloridis (Kaplan et al., 1968; Newman et al., 1973; Guckian et al., 1978). Much evidence has accumulated that gram-negative pathogens are cleared from the site of infection most effectively through the phagocytic process and opsonisation appears to be more important than 
direct serum bactericidal activity. In this study, phagocytic killing of $C$. pyloridis occurred in the presence of serum concentrations that were not lethal to the bacteria in the absence of PMN. A requirement for specific antibodies in opsonisation of $C$. pyloridis was established by the observation that homologous antiserum at a concentration which itself did not support substantial phagocytic killing dramatically increased killing in the presence of normal serum. Moreover, absorption of serum with the homologous strain of $C$. pyloridis prevented killing and replenishment of the absorbed serum with low levels of immune serum restored completely opsonophagocytic killing. These results support data describing the requirement for antibodies for optimal phagocytosis of other bacterial species (Bjornson and Michael, 1974; Verbrugh et al., 1979).

The participation of complement was determined by use of sera depleted of various complement components. Depletion of the classical complement pathway by chelation of calcium ions with EGTA significantly inhibited serum-mediated phagocytic killing; moreover, serum depleted of factor B

\section{REFERENCES}

Bienenstock J, Perey D Y E 1972 Immune mechanisms of mucosal resistance. Medical Clinics of North America 56: $391-402$.

Bjornson A B, Michael J G 1974 Factors in human serum promoting phagocytosis of Pseudomonas aeruginosa. 1. Interaction of opsonins with the bacterium. Journal of Infectious Diseases 130 Suppl: S119-S126.

Blaser M J, Duncan D J 1984 Human serum antibody response to Campylobacter jejuni infection as measured in an enzymelinked immunosorbent assay. Infection and Immunity 44: 292-298.

Eldridge J, Lessells A M, Jones D M 1984 Antibody to spiral organisms on gastric mucosa. Lancet 1 : 1237.

Fierer J, Finley F, Braude A I 1972 A plaque assay on agar for detection of gram-negative bacilli sensitive to complement. Journal of Immunology 109: 1156-1158.

Fine D P, Marney S R, Colley D G, Sergent J S, Des Prez R M 1972 C3 shunt activation in human serum chelated with EGTA. Journal of Immunology 109: 807-809.

Götze O, Müller-Eberhard H J 1971 The C3-activator system: an alternate pathway of complement activation. Journal of Experimental Medicine 134: 90s-108s.

Guckian J C, Christensen W D, Fine D P 1978 Evidence for quantitative variability of bacterial opsonic requirements. Infection and Immunity 19: 822-826.

Hill R, Pearman J, Worthy P, Caruso V, Goodwin S, Blincow E. 1986 Campylobacter pyloridis and gastritis in children. Lancet 1: 387.

International Journal of Systematic Bacteriology 1985 Validation of the publication of new names and new combinations previously, effectively, published outside the IJBS. List no. lacked opsonic activity. These data indicate the requirement for complete expression of complement activity for optimal phagocytic killing of $C$. pyloridis by PMN.

It is conjectural whether bacteria at the site of colonisation on the gastric mucosa are exposed to sufficient concentrations of complement and specific antibody to effectively opsonise the bacteria to the PMN infiltrate. We have frequently observed stained preparations of $C$. pyloridis-positive biopsy specimens in which bacteria were visible within PMNs but the role of defence components at the site of colonisation by $C$. pyloridis requires further study.

In addition, the function of $\operatorname{IgA}$ needs to be considered. IgA is the predominant class of immunoglobulin at mucosal surfaces and it does not promote phagocytosis (Bienenstock and Perey, 1972). Its role in modulating the clearance of $C$. pyloridis is unknown.

This work was supported by a grant from the Flinders Medical Centre Research Foundation (1985) to PCL and HP. We are grateful for the secretarial help of Miss Debbi Sullivan.

17. International Journal of Systematic Bacteriology 85 : 223225.

Johnston R B, Baehner R L 1971 Chronic granulomatous disease: correlation between pathogenesis and clinical findings. Pediatrics 48: 730-739.

Jones D M, Lessells A M, Eldridge J 1984 Campylobacter like organisms on the gastric mucosa: culture, histological, and serological studies. Journal of Clinical Pathology 37: 10021006.

Kaplan E L, Laxdal T, Quie P G 1968 Studies of polymorphonuclear leukocytes from patients with chronic granulomatous disease of childhood: bactericidal capacity for streptococci. Pediatrics 41 : 591-599.

Langenberg M L, Tytgat G N J, Schipper M E I, Rietra P J G M, Zanen H C 1984 Campylobacter-like organisms in the stomach of patients and healthy individuals. Lancet $1: 1348$.

Marshall B J, Warren J R 1984 Unidentified curved bacilli in the stomach of patients with gastritis and peptic ulceration. Lancet 1: 1311-1315.

Marshall B J, McGechie D B, Rogers P A, Glancy R J $1985 a$ Pyloric campylobacter infection and gastroduodenal disease. Medical Journal of Australia 142: 439-444.

Marshall B J, Armstrong J A, McGechie D B, Glancy R J 1985b Attempts to fulfil Koch's postulates for pyloric campylobacter. Medical Journal of Australia 142: 436-439.

Newman S L, Waldo B, Johnston R B 1973 Separation of serum bactericidal and opsonizing activities for Haemophilus influenzae Type b. Infection and Immunity 8: 488-490.

Phillips A D, Hine K R, Holmes G K T, Woodings D F 1984 Gastric spiral bacteria. Lancet 2: 100-101.

Platts-Mills T A E, Ishizaka K 1974 Activation of the alternate pathway of human complement by rabbit cells. Journal of Immunology 113: 348-358. 
Rollason J P, Stone J, Rhodes J M 1984 Spiral organisms in endoscopic biopsies of the human stomach. Journal of Clinical Pathology 37: 23-26.

Rowley D 1954 The virulence of strains of Bacterium coli for mice. British Journal of Experimental Pathology 35: 528538.

Shousha S, Bull T B, Parkins R A 1984 Gastric spiral bacteria. Lancet 2: 101.
Verbrugh H A, Van Dijk W C, Peters R, Van Der Tol M E, Peterson P K, Verhoef J 1979 Staphylococcus aureus opsonization mediated via the classical and alternate complement pathways. A kinetic study using Mg EGTA chelated serum and human sera deficient in IgG and complement factors CIs and C2. Immunology 36: 391-397.

Warren J R 1983 Unidentified curved bacilli on gastric epithelium in active chronic gastritis. Lancet 1: 1273. 